\title{
First record of the parasitoid wasp Lymeon sp. (Ichneumonidae: Cryptinae) associated with spider eggs-sac of Araneus vincibilis (Araneae: Araneidae) in Northeastern Brazil
}

\author{
J. F. Sobczak ${ }^{a}$ (D), G. A. Villanueva-Bonilla ${ }^{b *}$ (D), C. P. Silva ${ }^{a}$ (D), B. K. Souza-Santiago ${ }^{a}$ \\ and A. M. Penteado-Dias ${ }^{c}$
}

anstituto de Ciências Exatas e da Natureza, Universidade da Integração Internacional da Lusofonia Afro-Brasileira, Rod. CE 060, CEP 62790-000, Acarape, CE, Brasil

'Programa de Pós-graduação em Biologia Animal, Universidade Estadual de Campinas, Rua Monteiro Lobato, 255, CP 6109, CEP 13083-970, Campinas, SP, Brasil

'Departamento de Ecologia e Biologia Evolutiva, Universidade Federal de São Carlos - UFSCar, Rod. Washington Luis, Km 235, CEP 13565-905, São Carlos, SP, Brasil

*e-mail: germanvillanueva9@gmail.com

Received: January 29, 2019 - Accepted: May 02, 2019 - Distributed: August 31, 2020

(With 1 figure)

\begin{abstract}
Lymeon Förster, 1869 is a very large genus of the Cryptinae (Ichneumonidae) with predominantly Neotropical distribution where females attack small cocoons of various groups of insects and spider eggs-sac. In the present study, we report the first record the interaction between the parasitoid wasp Lymeon sp. (Ichneumonidae), with eggs-sac of spider Araneus vincibilis (Araneidae) in Northeastern Brazil. We observed that although the female of $A$. vincibilis cares for the eggs that were attacked by Lymeon sp, the wasp larva consumed about $80 \%$ of spider eggs, indicating that both maternal care and the physical barrier offered by the eggs-sac may not provide absolute defense against predators.
\end{abstract}

Keywords: biodiversity, Serra de Baturité, eggs-sac spider predator.

\section{Primeiro registro da vespa parasitóide Lymeon sp. (Ichneumonidae: Cryptinae) associada ao ovissaco da aranha Araneus vincibilis (Araneae: Araneidae) no Nordeste do Brasil}

\section{Resumo}

Lymeon Förster, 1869 é um grande gênero de Cryptinae (Ichneumonidae) com distribuição predominantemente neotropical, onde fêmeas atacam pequenos casulos de vários grupos de insetos e ovissacos de aranha. No presente estudo, relatamos o primeiro registro da interação entre a vespa parasitoide Lymeon sp. (Ichneumonidae), com o ovissaco da aranha Araneus vincibilis (Araneidae) no Nordeste do Brasil. Observamos que, embora a fêmea de A. vincibilis cuide dos ovos que foram atacados por Lymeon sp, a larva da vespa consumiu cerca de $80 \%$ dos ovos da aranha, indicando que tanto o cuidado maternal quanto a barreira física oferecida pelo ovissaco não podem fornecer defesa absoluta contra predadores.

Palavras-chave: biodiversidade, Serra de Baturité, predador de ovissaco de aranha.

\section{Introduction}

Ichneumonidae is one of the most species-rich families of Hymenoptera, with approximately 23,000 valid described species worldwide (Yu et al., 2012; Quicke, 2015). All members are endo or ectoparasitoids of other arthropods including larvae and pupae of Coleoptera, Hymenoptera and Lepidoptera (Camargo et al., 2015; Pereira et al., 2015; Morales-Silva et al., 2018). Some ichneumonid wasps like the Polysphincta genus-group (sensu Gauld and Dubois, 2006), are well known to act exclusively as koinobiont ectoparasitoid on various groups of spiders (e.g. Sobczak et al., 2017). On the other hand, some groups are predators of spider eggs where can consume up to $100 \%$ of the eggs (Villanueva-Bonilla et al., 2016).

Cryptinae is one of the largest subfamilies within Ichneumonidae with 397 recognized genera and some 4,500 described species (Yu et al., 2012; Quicke, 2015). They include taxa with a large range of biologies, some attack naked hosts (e.g. the wasp Gambrus incubator 
Linnaeus, 1758 is a parasitoid of pupae of moths of the family Zygaenidae); some are idiobiont ectoparasitoids of weakly to strongly concealed hosts; some Cyptinae has evolved as a pseudohyperparasitoid like the genera Gelis and Lysibia; a few attack pseudoscorpion egg masses (Phygadeuontini, Obisiphaga); and some are strictly predators within spider egg cocoons (e.g. Hydrata sordida Tschek 1870 reared from egg cocoons of the Lycosidae spider Pardosa pullata Clerck, 1757) (Schwarz and Shaw, 1999). In the Neotropical region there are few studies involving Cryptinae wasps acting as spider egg predators.

Lymeon Förster, 1869 is a very large genus of the tribe Cryptini within the subfamily Cryptinae with predominantly Neotropical distribution (Yu et al., 2012; Kasparyan, 2017). Currently, Cryptinae is represented by about 86 species of which four are found only in the Nearctic region (Townes and Townes, 1962). Species of this genus generally inhabit dense vegetation of forests where females attack small cocoons of various groups of insects and spider eggs-sac (Townes, 1970). The vast majority of studies with this genus describe new species where nothing is mentioned about the biology of the individuals (e.g. Kasparyan, 2004; Kasparyan and Ruíz-Cancino, 2008; Kasparyan, 2017).

Recently, in the forest reserve of the Hotel Remanso de Serra, Ceará State, Northeast of Brazil, we collected eggs-sacs of the spider Araneus vincibilis Keyserling, 1893 (Araneae: Araneidae) which contained cocoons of the wasp Lymeon sp. In this study we present the first record of predation of $A$. vincibilis spider eggs by the wasp Lymeon sp. We also present biological information about the spider host.

\section{Material and Methods}

This study was conducted in a Montane semi-deciduous tropical forest (Figure 1A) located in the municipally of Pacoti, Ceará State, Brazil (4¹3'30”'S 385'22”W, altitude of $736 \mathrm{~m}$ ). This area presents mean annual temperature of $21.5^{\circ} \mathrm{C}$ and average precipitation of $1,524 \mathrm{~mm}$.

We collected eggs-sacs of Araneus vincibillis on April 21, 2018 on a trail in the forest reserve of the Hotel Remanso de Serra during all the day. In field, the eggs-sacs were photographed and kept the in plastic recipients $(8 \times 10 \times 10 \mathrm{~cm})$ sealed with tulle fabric to obtain the adult wasps, along with the adult spider. In the Laboratory of Ecology and Evolution of UNILAB, adult spiders were preserved in alcohol for later identification. Under stereomicroscope, eggs-sac were carefully opened to verify the predation and accounting the eggs. The pupa of the Ichneumonidae were removed and kept in separate pots, sealed with tulle, until the adult wasps emerged from the cocoons. The voucher specimens of wasps were sent to the Coleção de Hymenoptera Parasitoides da Universidade Federal de São Carlos, São Carlos, São Paulo State (DCBU; curator A.M. Penteado-Dias) and spiders were sent to the collection of the Instituto Butantan, São Paulo, São Paulo State (IBSP, curator A.D. Brescovit).

\section{Results}

Araneus vincibillis (Figure 1D) wraps the eggs with silk inside a sheet used as a shelter. The sheet is then sealed with another layer of silk (Figure 1B, C). The orbicular web is constructed from the shelter leaf with the eggs (Figure 1B).

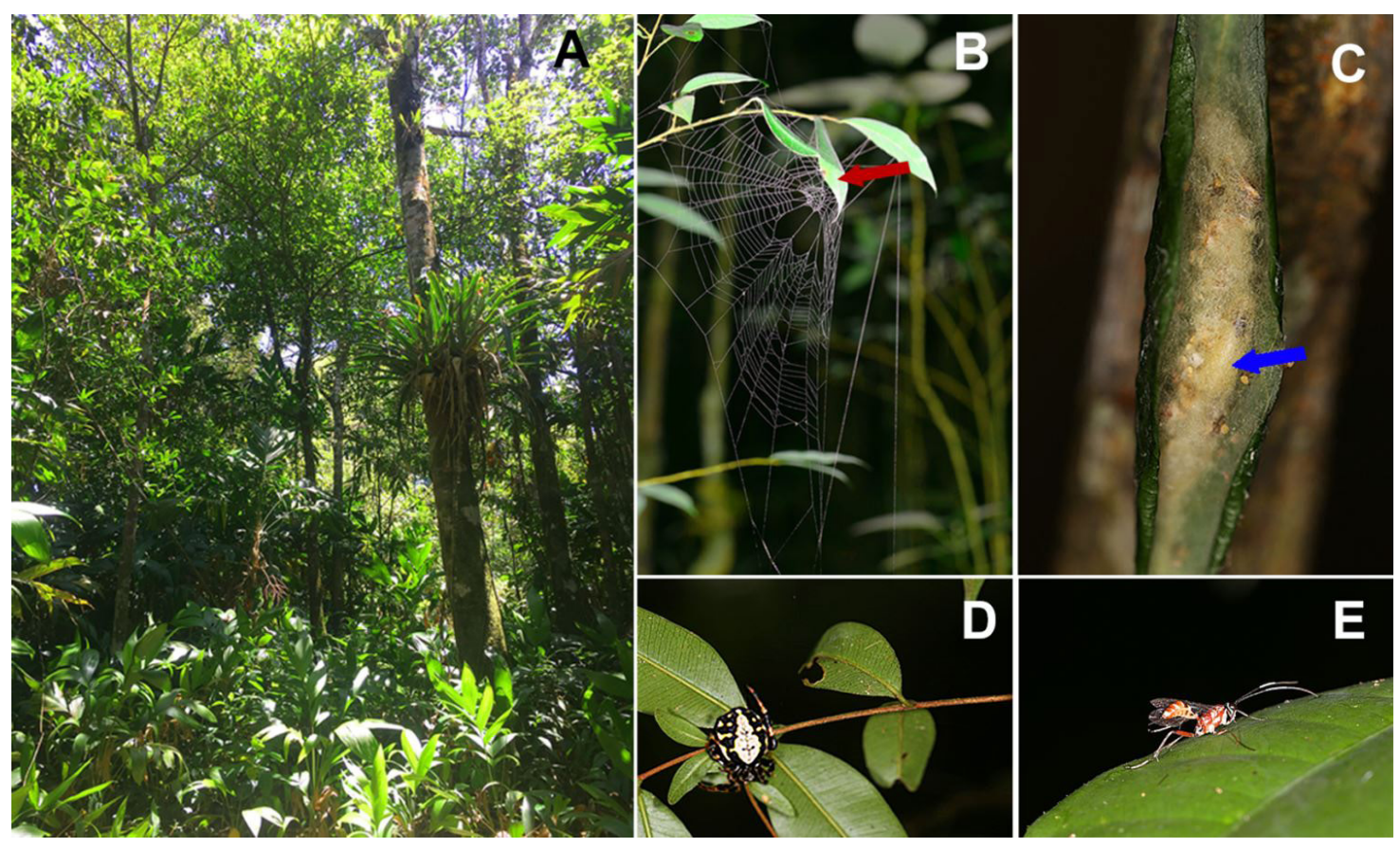

Figure 1. Araneus vincibilis and Lymeon sp. interaction. A) Montane semi-deciduous tropical forest in the Municipally of Pacoti, Ceará State, Brazil. B) Orbicular web of A. vincibilis, the red arrow indicates the leaf on which the eggs-sac is placed. C) Egg sac collected under the shelter sheet with wasp larvae developing (blue arrow). D) Adult female of $A$. vincibilis E) Lymeon sp. adult female wasp. 
Table 1. Number of pupae of Lymeon sp. (Ichneumonidae: Cryptinae) found within the eggs-sacs of Araneus vincibillis during the month of April, on the trails of Hotel Remanso in Pacoti -Ceará, Brazil.

\begin{tabular}{lccc}
\hline & Spider Eggs & $\begin{array}{c}\text { Presence or no of female } \\
\text { spider }\end{array}$ & Lymeon sp. individuals \\
\hline Egg sac 1 & 230 & without female & 0 \\
Egg sac 2 & 15 & with female & 5 \\
Egg sac 3 & 304 & with female & 0 \\
Egg sac 4 & 165 & without female & 0 \\
Egg sac 5 & 331 & without female & 0 \\
\hline
\end{tabular}

We collected five eggs-sacs, of which one had Lymeon sp. larva feeding on the eggs (Table 1). In this open eggs-sac, we found five cocoons, where three of them had already emerged in the field, and two cocoons contained wasps still in pupae to emerge (Figure 1C). In laboratory, after five days, the adult wasps emerged. To leave the eggs-sac, the adult wasp cuts a hole in the outer web layer that seals the leaf. The eggs-sacs can contain from 230 - 331 eggs when not attacked. However, with the presence of the predatory wasps, $80 \%$ of offspring can be lost (Table 1 ). Only 15 spiderlings remained in the eggs-sac attacked by the wasp larvae.

\section{Discussion}

Spider eggs-sacs are subject to a wide variety of attacks of predators and parasitoids wasp of different families of Hymenoptera. In the present study, we report for the first time a Lymeon sp. wasp preying on spider eggs of A. vincibilis. To our knowledge, there is a unique record of Lymeon attacking spider eggs by the author Townes (1970); however, the manuscript has no details about the type of host spider. The larvae of Lymeon sp. observed in this study consumed about $80 \%$ of spider eggs. This is not unusual, as recorded for Cobb and Cobb (2004) about the attack of the wasps Gelis sp. (Ichneumonidae) and Baeus sp. (Platygastridae) on the spider eggs of Pardosa moesta Banks, 1892 (Lycosidae) and P. sternalis Thorell, 1877 (Lycosidae). In that study, some spiderlings might emerge because the number of larvae was low (Fitton et al., 1988; Schwarz and Shaw, 1999). On the other hand, other records show that the egg consumption could be complete, for example, Camera lunavenatrix Santos \& Onody, 2016 (Ichneumonidae: Cryptinae) consumed $100 \%$ of the eggs of the spider Selenops cocheleti Simon, 1880 (Selenopidae) (Villanueva-Bonilla et al., 2016). The genera Tromatobia (Ichneumonidae: Pimplinae) and Aprostocetus (Chalcidoidea: Eulophidae) also consume $100 \%$ of the eggs when they attack the eggs-sac of the spider Araneus omnicolor Keyserling, 1893 (Araneidae) (Sobczak et al., 2012, 2015). However, the observed percentage of eggs consumed in the present study should be taken with caution, since the amount of eggs inside registered eggs-sacs not predated showed high variation, indicating that other mortality factors occurred in the eggs-sac preyed by Lymeon.

Morse (1988) mentions that spiders can experience strong pressure by predatory wasps that cause spiders to exhibit behaviors that diminish the attack on eggs. Females of Misumena vatia Clerck, 1757 (Thomisidae), for example, take care of the egg masses over much or all of the period between egg-laying and emergence of the young from the eggs-sac (Morse, 1985). In our study, we observed the female of $A$. vincibilis taking care of the eggs that were attacked by Lymeon sp. indicating that both maternal care and the physical barrier offered by the eggs-sac may not provide absolute defense against predators. Similar results were observed in the spider M. vatia eggs-sacs attacked by Trychosis cyperia Townes, 1962 (Ichneumonidae: Cryptinae) which can consume from $60-100 \%$ of the eggs even with the care of the spider female (Morse and Fritz, 1987).

\section{Acknowledgements}

This study was financed in part by the Coordenação de Aperfeiçoamento de Pessoal de Nível Superior - Brasil (CAPES) - Finance Code 001 (G.A. Villanueva-Bonilla), Also were financially supported by Instituto Nacional de Ciência e Tecnologia dos Hymenoptera Parasitoides (HYMPAR/ Sudeste-CNPq/FAPESP/CAPES), CNPq-Universal proc. 446473/2014- 6 and FUNCAP- BPI proc. BP2-010700127.01.00/15, BP3-00139-00186.01.00/18(research grants to J. F. Sobczak).

\section{References}

CAMARGO, L.F., BRITO, R.A. and PENTEADO-DIAS, A.M., 2015. Redescription of Campoletis sonorensis (Cameron, 1886) (Hymenoptera, Ichneumonidae, Campopleginae), parasitoid of Spodoptera frugiperda (JE Smith, 1797) (Lepidoptera, Noctuidae) in Brazil. Brazilian Journal of Biology $=$ Revista Brasileira de Biologia, vol. 4, no. 4, pp. 989-998. http://dx.doi. org/10.1590/1519-6984.04914.

COBB, L.M. and COBB, V.A., 2004. Occurrence of parasitoid wasps, Baeus sp. and Gelis sp., in the egg sacs of the wolf spiders Pardosa moesta and Pardosa sternalis (Araneae, Lycosidae) in southeastern Idaho. Canadian Field Naturalist, vol. 118, no. 1, pp. 122-123. http://dx.doi.org/10.22621/cfn.v118i1.894.

FITTON, M.G., SHAW, M.R. and GAULD, I.D., 1988. Pimpline ichneumon-flies. Hymenoptera, Ichneumonidae (Pimplinae). Handbooks for The Identifcation of British Insects, vol. 7, no. 1, 1-110.

GAULD, I.D. and DUBOIS, J., 2006. Phylogeny of the Polysphincta group of genera (Hymenoptera: Ichneumonidae; 
Pimplinae): a taxonomic revision of spider ectoparasitoids. Systematic Entomology, vol. 31, no. 3, pp. 529-564. http://dx.doi. org/10.1111/j.1365-3113.2006.00334.x.

KASPARYAN, D. R., 2004. Four new species of Lymeon Förster and Latosculum Townes (Hymenoptera: Ichneumonidae, Cryptinae) from Honduras and Mexico. Proceedings of the Russian Entomological Society, vol. 75, pp. 27-34.

KASPARYAN, D.R. and RUÍZ-CANCINO, E., 2008. A new species of Lymeon Foerster from Mexico (Hymenoptera, Ichneumonidae: cryptini). Zoosystematica Rossica, vol. 17, no. 1, pp. 93-94.

KASPARYAN, D.R., 2017. Two new species of the genus Lymeon (Hymenoptera: Ichneumonidae: Cryptinae: Cryptini) from Mexico. Zoosystematica Rossica, vol. 26, no. 2, pp. 276-281. http://dx.doi. org/10.31610/zsr/2017.26.1.276.

MORALES-SILVA, T., MAIA, L.F., MARTINS, A.L. and MODESTO-ZAMPIERON, S.L., 2018. Herbivore, parasitoid and hyperparasitoid insects associated with fruits and seeds of Enterolobium contortisiliquum (Vell.) Morong (Fabaceae). Brazilian Journal of Biology $=$ Revista Brasileira de Biologia, vol. 3, pp. 369-376. http://dx.doi.org/10.1590/1519-6984.170105. PMid:30231136

MORSE, D.H. and FRITZ, R.S., 1987. The consequences of foraging for reproductive success. In: A.C. KAMIL, J.R. KREBS and H.R. PULLIAM, eds. Foraging behavior. New York: Plenum, pp. 443-455. http://dx.doi.org/10.1007/978-1-4613-1839-2_14.

MORSE, D.H., 1985. Nests and nest-site selection of the crab spider Misumena vatia (Araneae: thomisidae). The Journal of Arachnology, vol. 13, pp. 383-390.

MORSE, D.H., 1988. Interactions between the Crab Spider Misumena Vatia (Clerck) (Araneae) and its Ichneumonid Egg Predator Trychosis cyperia Townes (Hymenoptera). The Journal of Arachnology, vol. 16, pp. 132-135.

PEREIRA, A.G., SILVA, R.B., DIAS, M.M. and PENTEADODIAS, A.M., 2015. Study on the Hymenoptera parasitoid associated with Lepidoptera larvae in reforestation and agrosilvopastoral systems at Fazenda Canchim (Embrapa Pecuária Sudeste) São Carlos, SP, Brazil. Brazilian Journal of Biology $=$ Revista Brasileira de Biologia, vol. 75, no. 4, pp. 783-789. http://dx.doi. org/10.1590/1519-6984.21913. PMid:26602340.
QUICKE, D.L.J., 2015. The braconid and ichneumonid parasitoid wasps: biology, systematics, evolution and ecology. New York: John Wiley and Sons, 704 p.

SCHWARZ, M. and SHAW, M.R., 1999. Western Palaearctic Cryptinae (Hymenoptera: Ichneumonidae) in the National Museums of Scotland, with nomenclatural changes, taxonomic notes, rearing records and special reference to the British check list. Part 2. Genus Gelis Tunberg (Phygadeuontini: Gelina). Entomologist's Gazette, vol. 49, pp. 101-127.

SOBCZAK, J.F., ALVARENGA, T.M. and COSTA, V.A., 2015. Occurrence of Aprostocetus sp. (Hymenoptera: Eulophidae), a predator on the eggs of Araneus omnicolor (Araneae: Araneidae), in Jundiai, Brazil. Revista Ibérica de Aracnología, 26, 95-97.

SOBCZAK, J.F., LOFFREDO, A.P.S. and SOBCZAK, J.C.M.S.M., 2012. First record of egg sac predation of the wasp Tromatobia sp. Foster, 1869 (Hymenoptera: Ichneumonidae) upon Araneus omnicolor (Keyserling, 1893) (Araneae: Araneidae). Revista Ibérica de Aracnología, vol. 20, 113-115.

SOBCZAK, J.F., VILLANUEVA-BONILLA, G.A., PÁDUA, D.G. and MESSAS, Y.F., 2017. The wasp Flacopimpla varelae Gauld (Ichneumonidae: Pimplinae), parasitoid of the spider Achaearanea tingo Levi (Theridiidae: Theridiinae), with description of the male wasp. Zootaxa, vol. 4365, no. 5, pp. 594-599. http:// dx.doi.org/10.11646/zootaxa.4365.5.7. PMid:29686193.

TOWNES, H.K. and TOWNES, M., 1962. Ichneumon-flies of America North of Mexico pt. 3: subfamily Gelinae, tribe Mesostenini. Bulletin of the United States National Museum, no. 216, pp. 1-602. http://dx.doi.org/10.5479/si.03629236.216.1-3.

TOWNES, H.K., 1970. The genera of Ichneumonidae, Part 2. Memoirs of the American Entomological Institute, vol. 12, pp. 1-537.

VILLANUEVA-BONILLA, G.A., ONODY, H.C., SANTOS, B.F. and VASCONCELLOS-NETO, J., 2016. First record of egg sac predation on a wall crab spider Selenopidae (Araneae) by the wasp Camera lunavenatrix sp. n. (Ichneumonidae, Cryptinae). Journal of Hymenoptera Research, vol. 49, pp. 65-79. http:// dx.doi.org/10.3897/JHR.49.7862.

YU, D.S., VAN ACHTERBERG, C. and HORSTMANN, K., 2012. World Ichneumonoidea 2011 - Taxonomy, biology, morphology and distribution. Canadá: Taxapad 2011. 